\title{
The first occurrence of the Order Mormonilloida (Copepoda) in the Tropical Southwest Atlantic Ocean
}

\author{
PEDRO AUGUSTO M.C. MELO ${ }^{1}$, MAURO DE MELO JÚNIOR ${ }^{2}$, \\ MOACYR ARAÚJO ${ }^{1}$ and SIGRID NEUMANN-LEITÃ ${ }^{1}$ \\ ${ }^{1}$ Universidade Federal de Pernambuco, Departmento de Oceanografia, \\ Av. Arquitetura, s/n, Cidade Universitária, 50670-901 Recife, PE, Brasil \\ ${ }^{2}$ Universidade Federal Rural de Pernambuco, Unidade Acadêmica de Serra Talhada, \\ Fazenda Saco, s/n, Zona Rural, 56903-070 Serra Talhada, PE, Brasil \\ Manuscript received on October 3, 2013; accepted for publication on September 6, 2014
}

\begin{abstract}
This communication is the first report of the occurrence of the order Mormonilloida (Mormonilla phasma) in the tropical Southwestern Atlantic Ocean. Female individuals were found in surface waters from the shelf break state of Rio Grande do Norte (Northeastern Brazil) and between depths of 60 and $100 \mathrm{~m}$ in the epipelagic layer around the St. Peter and St. Paul Archipelago (equatorial Atlantic). This finding extends the vertical limits for this species.
\end{abstract}

Key words: Copepod, equatorial, Mormonilloida, Mormonilla phasma, oceanic island, zooplankton.

\section{INTRODUCTION}

The genus Mormonilla was initially described by Giesbrecht in 1891 and placed in a separate family, Mormonillidae. Due to the combination of the characters of superorders Podoplea and Gymnoplea that the group presented, its position in the classification of Copepoda, long remained uncertain (Boxshall 1979). After several attempts to define the best classification, Boxshall (1979) proposed the elevation of the family to ordinal level, thereby creating the order Mormonilloida.

The order Mormonilloida includes two genera, Mormonilla and Neomormonilla, comprising five species. The genus Mormonilla has two species, $M$.

Correspondence to: Pedro Augusto Mendes de Castro Melo E-mail: pedroamcm@gmail.com minor Giesbrecht, 1891 and M. phasma Giesbrecht, 1891, which are widely distributed in oceanic waters between depths of 400 and $4000 \mathrm{~m}$ (Boxshall 2001). Boxshall and Halsey (2004) emphasize that approximately $90 \%$ of the population is concentrated between depths of 400 and $700 \mathrm{~m}$ in the shallow zone of the mesopelagic environment. These authors suggest that specimens may occasionally occur in shallow hauls from a depth of $300 \mathrm{~m}$.

Scott (1893) first recorded the species for the equatorial Atlantic in the Gulf of Guinea. In the database created by Razouls et al. (2005-2012), the species is cited for the Brazil-Argentina geographical area. However, the papers listed in this database suggest the occurrence of the species just off the coast of Africa and in the North Atlantic (Figure 1). 


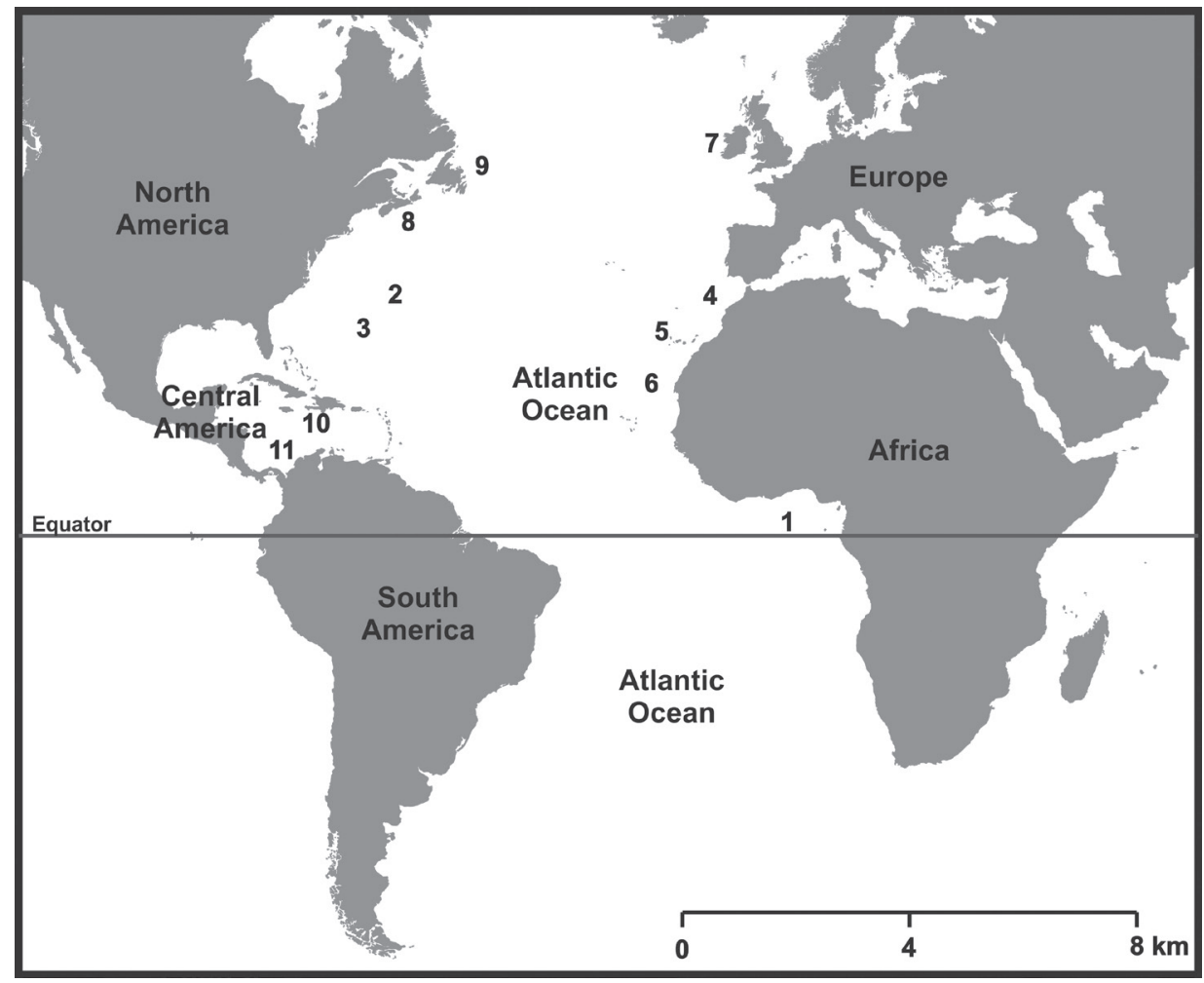

Figure 1 - Studies that recorded Mormonilla phasma (Mormonilloida) from the Atlantic Ocean, compiled from Razouls et al. (2005-2012). 1: Equatorial Atlantic (Gulf of Guinea) (Scott 1893), 2: NW Atlantic (Grice 1963), 3: NW Atlantic (off Bermuda) (Deevey and Brooks 1977), 4: NE Atlantic (Morocco, Mauritania) (Vives 1982), 5: NE Atlantic (Canary Is.) (Lozano Soldevilla et al. 1988), 6: NW African Coast (Huys et al. 1992), 7: N Atlantic (Ireland) (Holmes 2001), 8: NW Atlantic (off E Nova Scotia) (Sameoto et al. 2002), 9: NW Atlantic (Ivanenko and Defaye 2006), 10: Caribbean Sea (Morales-Ramirez and Suarez-Morales 2008), 11: NW Atlantic (Colombian Caribbean) (Medellín-Mora and Navas S 2010).

The purpose of this communication is to furnish the first report of the occurrence of the Order Mormonilloida (Mormonilla phasma Giesbrecht, 1891) in the tropical Southwest Atlantic Ocean and to extend its vertical limits for epipelagic waters.

The specimens were collected in two regions of the Brazilian waters: (i) the St. Peter and St. Paul Archipelago (SPSPA) and (ii) the shelf break of the state of Rio Grande do Norte (Potiguar Basin). At the SPSPA, vertical hauls were conducted from $100 \mathrm{~m}$ up to the surface in layers of $20 \mathrm{~m}$ with an opening-closing plankton net of $200 \mu \mathrm{m}$ mesh size. In the Potiguar Basin, transects were delimited perpendicular to the coastline, with stations located on the 150, 400, 1000 and $2500 \mathrm{~m}$ isobaths. At these stations, horizontal hauls were conducted in the nuclei of the main water masses (Tropical Water, South Atlantic Central Waters, Antarctic Intermediary Water, North Atlantic Deep Water) using a multinet with a $300 \mu \mathrm{m}$ mesh size.

At the SPSPA, 60 samples were analyzed, with individuals of $M$. phasma observed only in three of these samples. Five individuals of M. phasma were recorded during the dry season (Sep-Oct 2011), and the density varied from 0.16 to 1.44 ind. $\mathrm{m}^{-3}$ (Table I). The individuals were observed in the $60-80 \mathrm{~m}$ and $80-100 \mathrm{~m}$ layers downstream and upstream of the SPSPA, respectively (Table I). The oceanic dynamics that act on the SPSPA are subject to the influence of the Equatorial South 
TABLE I

Samples in which Mormonilla phasma (Mormonilloida) occurred at the Saint Peter and Saint Paul Archipelago and Potiguar Basin (RN).

\begin{tabular}{|c|c|c|c|c|c|c|c|c|}
\hline $\begin{array}{l}\text { Study } \\
\text { Area }\end{array}$ & Latitude & Longitude & Water Mass & Depth & Time & Date & No. specimens & $\begin{array}{l}\text { Density } \\
\left(\text { ind. }^{-3}\right)\end{array}$ \\
\hline \multirow{3}{*}{$\begin{array}{l}\mathbb{\Omega} \\
\tilde{\sim} \\
\tilde{\omega}\end{array}$} & $00^{\circ} 55,060 \mathrm{~N}$ & $29^{\circ} 20,393 \mathrm{~W}$ & TW & $80-100 m$ & Day & Sep/2011 & 2 & 1.44 \\
\hline & $00^{\circ} 54,979 \mathrm{~N}$ & $29^{\circ} 21,076 \mathrm{~W}$ & TW & $60-80 \mathrm{~m}$ & Day & $\mathrm{Sep} / 2011$ & 1 & 0.16 \\
\hline & $00^{\circ} 55,060 \mathrm{~N}$ & $29^{\circ} 20,393 \mathrm{~W}$ & TW & $80-100 \mathrm{~m}$ & Night & Oct/2011 & 2 & 1.33 \\
\hline \multirow{8}{*}{ 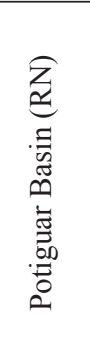 } & $04^{\circ} 47,32 \mathrm{~S}$ & $036^{\circ} 09,39 \mathrm{~W}$ & SACW & $260 \pm 2 \mathrm{~m}$ & Day & Nov/2009 & 1 & 0.06 \\
\hline & $04^{\circ} 46,42 \mathrm{~S}$ & $036^{\circ} 09,16 \mathrm{~W}$ & SACW & $365 \pm 2 \mathrm{~m}$ & Day & Dec/2009 & 10 & 0.32 \\
\hline & $04^{\circ} 46,42 \mathrm{~S}$ & $036^{\circ} 09,16 \mathrm{~W}$ & AIW & $810 \pm 2 \mathrm{~m}$ & Day & Dec/2009 & 7 & 0.27 \\
\hline & $04^{\circ} 36,90 \mathrm{~S}$ & $036^{\circ} 31,69 \mathrm{~W}$ & SACW & $350 \pm 2 \mathrm{~m}$ & Day & Nov/2009 & 5 & 0.05 \\
\hline & $04^{\circ} 39,18 \mathrm{~S}$ & $036^{\circ} 31,69 \mathrm{~W}$ & SACW & $410 \pm 2 \mathrm{~m}$ & Day & Nov/2009 & 3 & 0.07 \\
\hline & $04^{\circ} 39,18 \mathrm{~S}$ & $036^{\circ} 31,69 \mathrm{~W}$ & AIW & $925 \pm 2 \mathrm{~m}$ & Day & Nov/2009 & 46 & 0.21 \\
\hline & $04^{\circ} 39,18 \mathrm{~S}$ & $036^{\circ} 31,69 \mathrm{~W}$ & NADW & $1600 \pm 2 \mathrm{~m}$ & Day & Nov/2009 & 22 & 0.17 \\
\hline & $04^{\circ} 260,34 \mathrm{~S}$ & $036^{\circ} 25,92 \mathrm{~W}$ & NADW & $1600 \pm 2 \mathrm{~m}$ & Day & Nov/2009 & 11 & 0.10 \\
\hline
\end{tabular}

Stream (ESS) and Sub-Equatorial Current (SEC) (Araújo and Cintra 2009). The ESS flows EastWest; the SEC flows eastbound over the equator, just beneath the surface (Stramma 1991). The SEC splits in the immediate vicinity of Cape St. Roque to produce the Northern Brazil Current (NBC) and the Brazil Current (BC) (Richardson and Walsh 1986). At Potiguar Basin, 105 individuals of $M$. phasma were recorded in eight samples of the total of 28 analyzed. All specimens collected were females, with a density varying between 0.05 and 0.32 ind. $\mathrm{m}^{-3}\left(0.16 \pm 0.10\right.$ ind. $\left.\mathrm{m}^{-3}\right)$ (Table I). The individuals were collected between 260 and $1600 \mathrm{~m}$, with the higher concentrations occurring from 365 to $810 \mathrm{~m}$ (Table I). The females of this species are considered to be small-particle feeders (Boxshall 1985). The males, characterized by reduced feeding appendages and modified antennules, are interpreted as nonfeeding (Huys et al. 1992) and are extremely rare (Böttger-Schnack 1996). Specimens were deposited in the Crustacea collections of the Museu Oceanográfico Petrônio Alves Coelho (MOUFPE), Federal University of Pernambuco (MOUFPE No. 15123 - 15133).

M. phasma is considered to be restricted to the bathypelagic (Böttger-Schnack 1996) or mesopelagic zones (Boxshall and Halsey 2004, Ivanenko and
Defaye 2006). However, the specimens collected at the SPSPA were found between 60 and $100 \mathrm{~m}$. As far as we know, this record represents the first time that this species has been obtained at such a shallow depth in tropical waters. Although the genera Mormonilla (M. minor) and Neomormonilla ( $N$. polaris) have been observed in shallow cold waters near the North Pole (Deevey and Brooks 1977, Ivanenko and Defaye 2006), this pattern has not been found for tropical or subtropical waters, where the surface temperature is high $\left(>25^{\circ} \mathrm{C}\right)$. Shimode et al. (2006) observed in Sagami Bay (Japan) that $M$. phasma has not been collected in layers above 100 $\mathrm{m}$ and that the species most often occurs between 200 and $1000 \mathrm{~m}$. Longhurst (1985), studying the tropical Pacific Ocean, notes the occurrence of Mormonilla just under $100 \mathrm{~m}$. In the Potiguar Basin, the specimens, in most cases, were observed just above the maximum limit of $300 \mathrm{~m}$ suggested by Boxshall and Halsey (2004).

The presence of this species above $100 \mathrm{~m}$ at the SPSPA may be related to upwelling events in the area. Araújo and Cintra (2009) emphasize that the interaction of the abrupt topography of the SPSPA with the northern branch of the South Equatorial Current (nSEC) causes the production of vortices, thermohaline circulation disturbances and potential 
mechanisms of local upwelling. The presence at the surface of deep-water species (Phaenna spinifera, Heterorhabdus papillifer, Pleurommama abdominalis, P. gracilis among others) at the SPSPA indicates the occurrence of upwelling events (Diaz et al. 2009, Melo et al. 2012).

The first record of $M$. phasma in Chilean waters confirmed that the species was restricted to deep water (Hidalgo et al. 2010).

Although this first record of the occurrence of M. phasma for the tropical SouthwestAtlantic Ocean is most likely due to the lack of taxonomic reports of copepods from the meso- and bathypelagic zones in this region, this study highlights an increase in the amplitude of the vertical distribution of $M$. phasma to above $100 \mathrm{~m}$, an important factor for the ecology of the species. In addition, the low densities observed in both regions $\left(<2\right.$ ind. $\left.\mathrm{m}^{-3}\right)$ demonstrate that M. phasma occurs in small populations in the Southwest Atlantic Ocean, even in deeper water $(\sim 1600 \mathrm{~m})$.

\section{ACKNOWLEDGMENTS}

We thank the Conselho Nacional de Desenvolvimento Científico e Tecnológico (CNPq) for funding the project developed in the SPSPA $(\mathrm{CNPq}$ 557150/2009-4) and for a PhD scholarship granted to PAMCM. We thank the Brazilian Navy for all of the support furnished for the collections made in the SPSPA and PETROBRAS S.A. for financing the project developed in the Potiguar Basin, RN. We thank Dr. Rony Huys and Dr. Eduardo Suarez-Morales for contributing to this work with collaboration and suggestions.

\section{RESUMO}

Esta nota é o primeiro registro da ocorrência de Mormonilla phasma (Copepoda) no Sudoeste do Oceano Atlântico Tropical. Indivíduos fêmeas foram encontrados em águas superficiais na quebra da plataforma do estado do Rio Grande do Norte (Nordeste do Brasil) e entre 60 e $100 \mathrm{~m}$ de profundidade, na camada epipelágica ao largo do Arquipélago de São Pedro e São Paulo (Atlântico Equatorial). Este achado estende o limite vertical da espécie.

Palavras-chave: Copépodes, equatorial, Mormonilloida, Mormonilla phasma, ilha oceânica, zooplâncton.

\section{REFERENCES}

ARAUjo M AND CINTRA M. 2009. Modelagem matemática da circulação oceânica na região equatorial do Arquipélago de São Pedro e São Paulo. In: HAZIN FHV (Ed), O Arquipélago de São Pedro e São Paulo: 10 anos de Estação Científica, Brasília: SECIRM, p. 107-114.

BÖTTGER-SCHNACK R. 1996. Vertical structure of small metazoan plankton, especially noncalanoid copepods. I. Deep Arabian Sea. J Plankton Res 18: 1073-1101.

Boxshall G. 2001. Copepoda (excl. Harpacticoida). In. COSTELLO MJ, EMBLOW C AND WHITE RJ (Eds), European register of marine species: a check-list of the marine species in Europe and a bibliography of guides to their identification, p. 252-268.

BOXSHALL GA. 1979. The planktonic copepods of the northeastern Atlantic Ocean: Harpacticoida, Siphonostomatoida and Mormonilloida. Bull Brit Mus Nat Hist Zool 35: 201-264.

BOXSHALL GA. 1985. The comparative anatomy of two copepods, a predatory Calanoid and a particle-feeding Mormonilloid. Philos Trans R Soc B: Biological Sciences 311: 303-377.

BoXshall GA AND Halsey SH. 2004. An introduction to copepod diversity. The Ray Society, 966 p.

DeEvey GB AND BROOKS AL. 1977. Copepods of the Sargasso Sea off Bermuda: Species Composition, and Vertical and Seasonal Distribution Between the Surface and $2000 \mathrm{~m}$. Bull Mar Sci 27: 256-291.

DiAZ XFG, GUSMÃo LMO AND NEUMANN-Leitão S. 2009. Biodiversidade e dinâmica espaço-temporal do zooplâncton. In: HAZIN F (Ed), O Arquipélago de São Pedro e São Paulo: 10 anos de Estação Científica. $1^{\mathrm{a}}$ ed., Brasilia: Comissão Interministerial Para os Recursos do Mar, 1: 139-149

GRICE GD. 1963. Deep water copepods from the western North Atlantic with notes on five species. Bull Mar Sci Gulf Caribb 13: 493-501.

HidAlgo P, ESCRIBANO R, VERGARA O, JORQUERA E, DONOSO K AND MENDOZA P. 2010. Patterns of copepod diversity in the Chilean coastal upwelling system. Deep Sea Res Pt II: Topical Studies in Oceanography 57: 2089-2097.

Holmes JMC. 2001. A checklist of the Calanoida and the smaller copepod orders (Crustacea: Copepoda) of Ireland. Bull Irish Biogeogr Soc 25: 7-73.

HuYs R, BOXSHALl GA AND BÖTTGER-SCHNACK R. 1992. On the discovery of the male of Mormonilla Giesbrecht, 1891 (Copepoda: Mormonilloida). Bull the Brit Mus Nat Hist Zool 58: 157-170. 
IVANENKo VN AND DEFAYE D. 2006. Planktonic Deep-water Copepods of the Family Mormonillidae Giesbrecht, 1893 from the East Pacific Rise (13N), the Northeastern Atlantic, and Near the North Pole (Copepoda, Mormonilloida). Crustaceana 79: 707-726.

LONGHURST AR. 1985. Relationship between diversity and the vertical structure of the upper ocean. Deep Sea Res Pt A Oceanographic Research Papers 32: 1535-1570.

Lozano Soldevilla F, Hernandez F, Ros MM, Jimenez S, Mingorance MC, Perez A and Consuelo DE LORENZO M. 1988. Preliminary list of zooplankton of the Canary Islands. I. Cladocera, Copepoda, Euphausiacea, Chetognatha and Salps. Bol Mus Munic Funchal 40: 55-64.

MEDELLÍN-MORA J AND NAVAS S GR. 2010. Listado taxonómico de copépodos (Arthropoda: Crustacea) del mar Caribe Colombiano. Bol Investig Mar Cost INVEMAR 39: 265-306.

MELO PAMC, DiAZ XFG, MACEDO SJ AND NEUMANN-LEITÃo S. 2012. Diurnal and spatial variation of the mesozooplankton community in the Saint Peter and Saint Paul Archipelago, Equatorial Atlantic. Mar Biodivers Rec 5: 1-14.

MorALES-RAMIREZ A AND SUAREZ-MORALES E. 2008. Copepods. Marine Biodiversity of Costa Rica, Central America, p. 291-305.

Razouls C, De Bovée F, Kouwenberg J AND Desreumaux N. 2005-2012. Diversity and Geographic Distribution of Marine Planktonic Copepods. http://copepodes.obsbanyuls.fr/en.
RICHARDSON PL AND WALSH D. 1986. Mapping climatological seasonal variations of surface currents in the tropical Atlantic using ship drifts. J Geophys Res 91: 10537-10550.

SAMEOTO DD, OCEANOGRAPHY BIO, Cochrane NA, FISHERIES CDO AND OCEANS. 2002. Seasonal Abundance, Vertical and Geographic Distribution of Mesozooplankton, Macrozooplankton and Micronekton in the Gully and Western Scotian Shelf (1999-2000). Ocean Sciences Division, Maritimes Region, Department of Fisheries and Oceans, Bedford Institute of Oceanography.

SCOTT T. 1893. Report on Entomostraca from the Gulf of Guinea, collected by John Rattray, B.Sc. Trans Linn Soc London (Zoology) 6: 1-161.

SHIMODE S, TODA T AND KIKUCHI T. 2006. Spatio-temporal changes in diversity and community structure of planktonic copepods in Sagami Bay, Japan. Mar Biol 148: 581-597.

STRAMMA L. 1991. Geostrophic transport of the South Equatorial Current in the Atlantic. J Mar Res 49: 281-294.

VIVES F. 1982. Sur les copépodes de la région CINECA (parties nord et centrale). In: HEMPEL G (Ed), The Canary Current: studies of an upwelling system: Rapports et Proces-verbaux des Réunions. Conseil International pour l'Éxploration de la Mer, p. 289-296. 
